\title{
Historein
}

Vol 14, No 1 (2014)

On the Edge of History and Philosophy

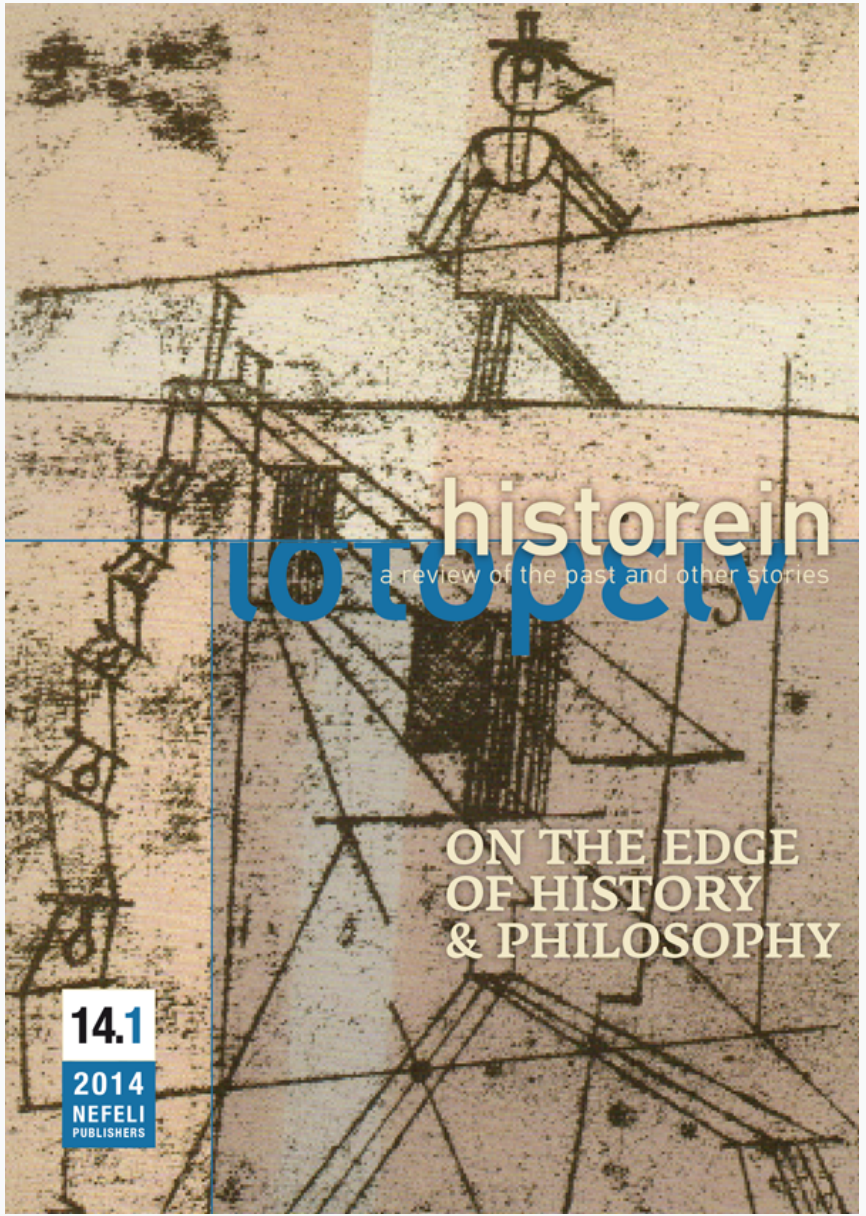

\section{Review of O. V. Sokolovskaia's Grecheskaia koroleva Ol'ga Konstantinovna - Pod molotom sud'by [The Greek queen Olga Konstantinovna: under the hammer of fate]}

Lucien James Frary

doi: $10.12681 /$ historein.258

Copyright ( 2014, Lucien James Frary

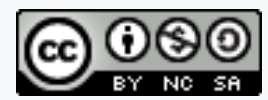

This work is licensed under a Creative Commons Attribution-NonCommercialShareAlike 4.0.

\section{To cite this article:}

Frary, L. J. (2014). Review of O. V. Sokolovskaia's Grecheskaia koroleva Ol'ga Konstantinovna - Pod molotom sud'by [The Greek queen Olga Konstantinovna: under the hammer of fate]. Historein, 14(1), 134-139.

https://doi.org/10.12681/historein.258 
by the failure of the negotiations on disarmament but by Greek apprehension, which was not necessarily founded on hard facts, about a potential Yugoslav-Bulgarian rapprochement. Still, there was an additional factor that pushed the anti-Venizelist government towards the conclusion of the pact - the changing dynamics of the national schism. Since 1922, Venizelos operated on the assumption that the end of the Megali Idea (Great Idea) as a policy permitted Greece to pursue a policy of noncommitment to alliances. In the mid-1930s, he was convinced that this policy was both desirable and feasible, despite the worsening international situation and the possibility of the re-emergence of blocs. His opponents, who won the March 1933 election, operated on assumptions that derived their validity from the first world war: Greece would not be able to follow a policy that contradicted the policy preferences of the dominant Mediterranean naval power. King Constantine's failure in May 1917 to continue a policy of Greek neutrality in the face of British and French opposition loomed large in anti-Venizelist memory and facilitated the undertaking of a policy of commitment to the Balkan pact. Venizelos' opposition to its conclusion served as a factor that crystallised these diverging assumptions and connected this disagreement over foreign policy to internal political dynamics.

All in all, it can be said that Greek foreign policy was not determined exclusively from the "forces profondes" or the ideological preferences of distinguished politicians, diplomats and military men who were in positions of influence.

Missing from Koumas' analysis of the overall framework of Greek foreign policy in the concluding chapter of his otherwise interesting and important book is the domestic political factor, which would permits us to fully grasp Greek policymaking.

\section{O.V. Sokolovskaia}

Grecheskaia koroleva Ol'ga

Konstantinovna - Pod molotom sud'by

\section{[The Greek queen Olga Konstantinovna: under the hammer of fate]}

\section{Moscow: Institute of Slavic Studies, 2011. 212 pp.}

\section{Lucien J. Frary}

Rider University, USA

The reign of Queen Olga Konstantinovna of Greece (1867-1913) represents a landmark in the history of Russian-Greek relations. The founder of hospitals and schools, the patroness of prison reform and social welfare, Queen Olga was a resilient woman who made a strong impression on her people. A zealous letter writer, Olga bequeathed scholars with an abundance of materials that illuminate her private and public life during one of the most turbulent 50 years in European history. Disdainful of parliamentary politics as "filthy squabbling", her adept manoeuvring through the web of European dynastic relations brought benefits to her native and adopted homelands, and her integrity proved inspirational, especially during wartime. A genuinely popular figure (above all among soldiers and sailors), historians have neglected her story until now. ${ }^{1}$

O.V. Sokolovskaia, a doctor of history and member of the Institute of Slavic Studies in the Russian Academy of Sciences, has synthesised hundreds of letters from Olga's personal collection in the State Archive of the Russian Federation (GARF) into a sympathetic portrait of the queen and her age. Consisting of a prologue, ten short chapters, and an epilogue, 
the book establishes the author as the principal authority on the subject. Supplemented by files in the Archive of Imperial Russian Foreign Policy (AVPRI) and the Russian State Archive of the Navy (RGAVMF), the volume provides researchers with fresh material on a range of topics, from healthcare and biblical translation, to the movement for unification on Crete and the legacy of the Greek monarchy.

Olga Konstantinovna's life can be divided into two periods, with the Russian-Ottoman war of 1877-78 at the pivot: the first period is marked by domestic tranquillity; the second consists of international crisis, tragedy and exile. Born in the Pavlovskii Palace outside St Petersburg in 1855 to Grand Prince Konstantin Nikolaevich, the brother of Tsar Alexander II, Olga received a brilliant education from an impressive constellation of tutors, including the famous Russian historian S.M. Solov'ev. Unusually self-sacrificing, mild and sincere, Olga met her future husband for the first time in 1863, when the newly crowned king of Greece, George I (1864-1913), of the Glücksburg dynasty of Denmark, visited Russia to thank the tsar for supporting his election to the throne. Since both came from German mothers, their mutual language was German, and remained so throughout their long life together. A passion for the sea also strengthened the bond between the young couple. Returning to Russia in 1867, George proposed to the Russian grand duchess (six years his junior), whose religious pedigree helped establish the new dynasty as pre-eminently Orthodox. The couple married in a chapel within the Winter Palace. Fortunately, it was an extremely happy relationship, lasting 45 years and resulting in seven children, including the future kings Constantine I (1913-22) and George II (1922-24, 1935-47). Although utterly cosmopolitan, the royal couple raised their children as integrally Greek.
Before she became her majesty, most of what Olga knew of Greece came from books and tutors. Arriving in Athens as a teenager, Olga initially shied from public attention, focusing on raising her children, learning Greek (both demotic and katharevousa) and studying history under Konstantinos Paparrigopoulos. Several years later, she emerged as an astute and visible, yet politically disinterested, monarch who interacted well with the full spectrum of Greek society. Her amiable and attractive husband provided her with emotional and intellectual support and a meaningful home life. Although 39 governments served during King George's first 20 years, his political acumen, respect for liberalism and reverence for the church brought stability to his realm.

As she emerged as a public figure, Olga maintained strong ties to Russia, where the family holidayed almost every year. The royal couple and their children enjoyed St Petersburg's high culture, and mingled with elite artists, including A.A. Fet and P.I. Tchaikovsky. They also frequented the European capitals (George remarked "I am my own ambassador") and spent time at their personal estates on Corfu and at Tatoi. Raising their children in these idyllic settings, the royal couple refrained from ostentatious luxury, and emphasised pragmatism and diligence. In Athens, King George promoted modernisation programmes, including railway and canal construction, and engaged in beautifying projects, most notably the Royal Garden, while helping to organise the first modern Olympic Games in 1896. However, towards the end of the century, the state's deeply troubled finances and a disastrous war against the Ottomans interrupted the domestic bliss at home.

An important element of the queen's life consists of her correspondence with various European and Russian aristocrats, including her favourite younger brother, Konstantin Kon- 
stantinovich. Sokolovskaia's findings underscore the queen's linguistic facility: she wrote in Danish, English, German, French, Russian and Greek. Orthodoxy constitutes a central theme of her letters, which are often critical of "the sorry condition of the [Greek] clergy", shabby iconostases, ugly icons, and "the shortage of godliness in Greek churches" (77). At times chauvinistic, Olga detested Catholics and could exhibit extreme slavophile views. Yet she also remarked that "with the [Greek] people, with simple folk, I feel as one" (74), and she aimed to inspire the spiritual revival of her kingdom by founding churches, homes for invalids and centres for adolescent reform. In this respect, the book would have been enriched if Sokolovskaia had probed in depth the dual aspect of Olga's character, torn between the fires of hellenism and panslavism.

The Russian-Ottoman war of 1877-78 triggered Olga's commitment to public service. Championing both the Russian cause and Greek irredentism, she responded by organising relief for wounded soldiers and their families. Her activities helped offset russophobic tendencies prevalent within certain Greek circles. Olga's vivid letters demonstrate her enthusiasm for the Russian cause, especially as her brother Konstantin earned awards for military service. Although the San Stefano agreement outraged the Greek public, the Berlin treaty and the British acquisition of Cyprus balanced public opinion in Russia's favour. Throughout the war, Olga remained firmly behind Greek expansion and thus public criticism against her was unfounded. Ironically, warfare inspired perhaps the most important of the queen's philanthropic activities: Evangelismos hospital in Athens.

The suffering of war generated a remarkable sense of dedication in the queen. She showed great respect for veterans and "my wounded". Untroubled by the nitty-gritty aspects of surgery, she made daily calls at hospitals as a trained nurse, where she presented gifts to evzones in need. As their suffering increased, so did her admiration for them. Close association with gravely wounded individuals prompted her to sponsor a demotic translation of the Gospels. The 1901 edition, meant for "simple people, craving spiritual nourishment", (98) sold for one drachma, less than the cost of printing. An extremely delicate topic with a long history, Olga did not realise the maelstrom she opened by promoting the work. ${ }^{2}$ Again, we would have benefitted if Sokolovskaia had explored the rift between Olga's staunch conservatism and her liberal attitude towards biblical translation.

One of the more noteworthy aspects of Olga's epistolary legacy consists of her reflections on the struggle for enosis (unity) with Crete, which reached a zenith at the turn of the century. Calling on her formidable personal connections, Olga employed Orthodoxy, patriotism and moral outrage to urge intervention on behalf of the Greek Cretans. Her emotional letters to her cousin, Tsar Nicholas II (quoted at length by Sokolovskaia), convey Olga's commitment to the cause. The appointment of her son Prince George, whom she called an "Orthodox Greek" (113), to the post of governor of Crete, was due in part to Russian diplomatic pressure. Olga wrote to Tsar Nicholas that, "George on Crete seems to us as the only means of calming this long-suffering island" (117). Never content as a passive observer, Olga accompanied her son to the island, where she enjoyed visiting Russian soldiers stationed on the peacekeeping mission. "I absolutely love the nature and population [of Crete]," (124) wrote the queen. However, the brewing political showdown in Athens between monarchists and the "liberal bourgeoisie" stymied George's term as governor. Overall, in keeping 
with her sources, Sokolovskaia's assessment favours the prince over Eleftherios Venizelos, who comes off as a villain.

The Russian Mediterranean fleet on duty near Crete brought Queen Olga many opportunities to meet with Russian sailors. Coming from a naval background (her father was the Russian naval minister), Olga adored drinking tea with officers and listening to the stories of enlisted men, whom she presented with gifts and awards. An enormous portion of the queen's archive contains photographs of her onboard ship. Her experience led to the establishment of an exquisite Russian hospital and cemetery in Piraeus for soldiers returning from the Russo-Japanese war (1904-05). A gravely wounded cadet named M. lu. Garshin, whom she met in the hospital, later became her secretary. ${ }^{3}$ Thus, Olga earned her unique epithet of the "Queen Mother of the Russian Navy".

The outbreak of the Balkan wars in 1912 interrupted the queen's sojourn in Russia. She rushed home and spent the next year working at hospitals and service centres near the front. Visiting the wounded remained her passion, and her heartfelt letters express both distress and joy at the unfolding events. Thrilled by the Greek army's "liberation" of Thessaloniki - "Glory and thanks to God," she wrote, "this means the end of Turkey" (171) - she was extremely disappointed by the restrained peace terms of November 1912. Then tragedy struck, as a deranged Greek anarchist assassinated her much-loved husband, thus bestowing her with the unwanted title of "Widowed QueenMother of the Greeks". In despair, she sought comfort among relatives in Russia, as political conflicts raged in Greece.

When the first world war erupted, Olga was no stranger to crisis. Unable to return to Greece, she worked closely with the Russian
Red Cross to help thousands of wounded and maimed soldiers at field hospitals near her childhood home in Pavlovsk. She also engaged in morale-boosting campaigns and donation drives. Tragically, more sorrow befell her, as nephews, sons-in-law and her beloved brother died fighting at the front. Fleeing Russia in the wake of October 1917, she spent most of her last decade in exile.

A prolific historian steeped in archives, Sokolovskaia is one of the most active Russian specialists in modern Greek history. ${ }^{4}$ Her succinct, insightful and well-illustrated biography brings to light an admirable figure, struck by the hammer of fate. Whereas the popularity of royal family history may have declined among professional historians in recent decades, Sokolovskaia's book demonstrates the importance of this genre and its ability to illuminate a host of wider issues. For this reason, the author may have better integrated her study within the broader secondary literature. Most of all, the book reminds researchers of the wealth of untapped resources in Russian archives pertaining to Greek and Balkan history. Any serious student of the Cretan question at the turn of the century cannot ignore Sokolovskaia's work. The Institute of Slavic Studies in the Russian Academy of Sciences deserves praise for supporting projects like this one.

\section{NOTES}

1 The old biography by the a friend of the queen,

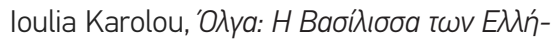
$v \omega v$ [Olga: Queen of the Greeks], Athens: Estia, 1938, remains valuable. See also Julia P. Gelardi, From Splendor to Revolution: The Romanov Women, 1847-1928, New York: St Martin's Press, 2011.

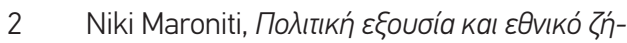

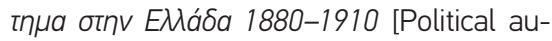


thority and the national question in Greece, 1880-1910], Athens: Alexandria, 2009; Philip Carabott, "Politics, Orthodoxy and the language question in Greece: the Gospel riots of November 1901," Journal of Mediterranean Studies 3/1 (1993): 117-138.

M. lu. Garshin, Koroleva ellinov Ol'ga Konstantinovna [Queen of the Greeks Olga Konstantinovna], Prague: Russkaia morskaia zarubezhnaia biblioteka, 1937. See also, www.archive.org/details/korolevaellinovo0088001 (accessed 12 Feb 2014).

Her previous publications include Rossiia na Krite: Iz istorii pervoi mirotvorcheskoi operatsii XX veka [Russia on Crete: From the history of the first peacekeeping operation of the 20th century], Moscow: Indrik, 2006, and Gretsiia v gody Pervoi mirovoi voiny, 1914$1918 \mathrm{gg}$ [Greece in the years of the First World War, 1914-1918], Moscow: Nauka, 1990. She is also the editor of Greki Balaklavy i Sevastopolia [The Greeks of Balaklava and Sevastopol], Moscow: Indrik, 2013. For a full bibliography, see www.inslav.ru/ob-institute/sotrudniki/746-2011-08-28-12-17-31 (accessed 12 Feb 2014).

\section{Maria Papathanassiou}

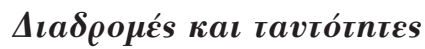

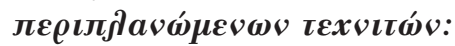

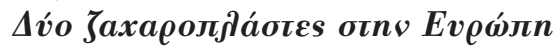

tov 19 ov alóva

\section{[Tramping artisans' routes and identities: Two journeymen- confectioners in nineteenth-century Europe]}

Athens: Smili, 2012. 290 pp.

\section{Anna Karakatsouli}

University of Athens

The tramping system, i.e. the practice of organised journeymen wandering in seek of work, survived well into the industrial era, with distinct functions according to local traditions and conditions. An old and living custom fully institutionalised in continental Europe in the form of the tour de France or Wanderpflicht, it was the final stage in the craftsman's education after his apprenticeship that gave him his artisan credentials. On the contrary, tramping in Britain served rather as a device for covering seasonal or irregular unemployment needs and to relieve strike funds in periods of struggle. Difficult to determine, the origins of the British variation remain an open question. Was it the expression of the artisan's new-found mobility, as has been suggested, or did it spring from an old and living tradition of journeyman travel? In any case, by removing the unemployed from places where trade was slack, and putting them in circulation, tramping kept the supply to the labour market limited. In Britain and on the continent alike, the tramping system provided the young single male artisan who wished to leave town to look for work elsewhere with a "blank", "clearance" or "document" showing him to be a member in good 